\title{
Intizar
}

Vol. 26, No. 1, Juni 2020

Website: http://jurnal.radenfatah.ac.id/index.php/intizar

ISSN 1412-1697, e-ISSN 2477-3816

\section{Resiliensi dan Kemiskinan: Studi Kasus}

\author{
Manah Rasmanah \\ Universitas Islam Negeri Raden Fatah Palembang, Indonesia, manahrasmarah_uin@radenfatah.ac.id
}

DOI: doi.org/10.19109/intizar.v26i1.5106

\begin{abstract}
Abstrak
Penelitian ini bertujuan untuk mengungkap gambaran resiliensi mahasiswa yang mengalami kesulitan ekonomi dan faktor yang mempengaruhi. Jenis penelitian ini kualitatif dengan pendekatan studi kasus. Subjek penelitian adalah seorang mahasiswa yang mengalami kesulitan ekonomi tetapi berprestasi akademik sebagai sumber primer dan seorang teman dekat subjek dan saudara kandung subjek sebagai sumber data sekunder. Teknik pengumpulan data yang digunakan adalah wawancara dan observasi. Data dianalisa menggunakan teknik analisis studi kasus menurut Robert K Yin yang terdiri dari penjodohan pola, eksplanasi dan deret waktu. Hasil penelitian menunjukkan bahwa mahasiswa memiliki resiliensi dalam menghadapi kesulitan ekonomi yang ditandai dengan kemampuan regulasi emosi, self efficacy yakni memiliki inisiatif, mampu menyelesaikan masalah, kreatif dan bertanggung jawab, optimis, mampu menganalisa masalah, memiliki motivasi berprestasi, mampu mengenali potensi diri, memiliki modal kesuksean dan telah memiliki pencapaian (prestasi akademik). Faktor yang mempengaruhi resiliensi adalah faktor internal berupa, keterampilan sosial, empati, konsep diri positif, self-efficacy dan self esteem, memiliki rasa kebermaknaan yakni optimisme, motivasi, minat, sistem keyakinan dan karakter yang humoris. Sedangkan faktor eksternal dipengaruhi oleh dukungan keluarga dan teman, norma keluarga dan rule model.
\end{abstract}

Kata Kunci: Resiliensi, Kemiskinan, Mahasiswa

\begin{abstract}
This study aims to uncover the picture of resilience of students who experience economic difficulties and influencing faktors. This type of research is qualitative with a case study approach. The subject of the study was a student who was experiencing economic difficulties but had academic achievements as a primary source and a close friend of the subject and siblings of the subject as a source of secondary data. Data collection techniques used were interviews and observation. Data were analyzed using a case study analysis technique according to Robert K Yin which consisted of pattern matching, explanation and time series. The results showed that students have resilience in the face of economic difficulties marked by the ability of emotional regulation, self efficacy that is having initiative, being able to solve problems, being creative and responsible, optimistic, being able to analyze problems, having achievement motivation, being able to recognize self potential, having capital success and have had achievements (academic achievements). Faktors that influence resilience are internal faktors such as sosial skills, empathy, positive self-concept, self-efficacy and self esteem, which have a sense of meaningfulness namely optimism, motivation, interest, belief systems and humorous character. While external faktors are influenced by the support of family and friends, family norms and rule models.
\end{abstract}

Keywords: Resilience, Poverty, Student

\section{Pendahuluan}

Bagi masyarakat miskin, kehidupan merupakan suatu perjuangan yang tidak ada habisnya (Juby \& Rycraft, 2004). Karena keluarga miskin cenderung memusatkan tenaganya untuk memperbaiki kondisi keuangan dari pada hubungan dalam keluarga atau pengasuhan (Orthner, Jones-Sanpei, \& Williamson,
2004). Hidup dalam kemiskinan juga dapat meningkatkan sumber stress keluarga, khususnya orang tua dan dapat berpengaruh pada sensitivitas keterlibatan pengasuhan yang bisa mengakibatkan putus asa pada anak (McLoyd, 1990), dan juga stress keluarga akibat kemiskinan ini secara tidak langsung 
dapat mempengaruhi ketidakstabilan interaksi dalam rumah tangga.

Tekanan keluarga miskin terkait keterbatasan ekonomi secara tidak langsung juga dapat mempengaruhi persepsi orang tua terkait pendidikan bagi anaknya. Sebuah penelitian yang dilakukan oleh Ronald Buck \& Joe Deutsch (2014) menjelaskan bahwa masyarakat miskin baik di perkotaan maupun di pedesaan menghadapi banyak masalah, misalnya hunian yang tidak layak, akses terhadap layanan profesional sangat rendah termasuk pendidikan. Pendidikan yang cenderung rendah disebabkan berbagai alasan, karena kemiskinan merupakan siklus masalah yang luas dan kompleks yang dapat mempengaruhi berbagai kehidupan seseorang. Dalam penelitian Pilih Karini (2018) menjelaskan bahwa angka partisipasi sekolah ada hubungannya dengan kemiskinan. Penelitian yang mengambil lokasi di provinsi Kepulauan Bangka Belitung, dengan melihat perkembangan dari tahun 2012 hingga 2016, memberi kesimpulkan bahwa semakin turun angka kemiskinan semakin naik angka partisipasi sekolah.

Namun tidak dipungkiri akan ada banyak tantangan yang harus dihadapi baik dari segi finansial dalam pemenuhan kebutuhan sehari-hari dan kebutuhan mendadak lainnya maupun dari segi akademik. Hal ini dikarenakan pemenuhan kebutuhan tersebut dapat mempengaruhi kemampuan bertahan dan penyesuaian diri di lingkungan kampus. Apalagi pada kehidupan remaja akhir menuju dewasa awal, dimana pada masa itu individu harus siap menghadapi tantangan serta kemandirian dalam mengatur hidupnya, seperti contoh individu yang akan memulai kuliah ataupun mulai masuk di dunia kerja, mereka harus hidup mandiri atau jauh dari orang tua, atau hidup dengan pasangannya. Dalam proses tersebut terkadang ada proses yang mengganggu dalam keseimbangan lingkungan sosial remaja. Pada dewasa awal ini diharapkan bisa menjadi pribadi yng lebih mandiri dan dapat menempatkan diri di posisi mereka di masyarakat. Dengan begitu, fase remaja akhir ini meruapakn fase yang tepat untuk mengetahui sejuh mana resiliensi yang dimilikinya dalam menjalani kehidupan terutama remaja dalam kondisi-kondisi beresiko (Milioni et al., 2015). Namun Crosnoe (2002) menyatakan bahwa terdapat banyak penelitian yang menunjukkan bahwa anak-anak dari keluarga miskin dan berstatus ekonomi rendah ternyata mampu mengikuti pendidikan akademik di sekolah meskipun mereka memiliki keterbatasan sumber ekonomi dalam keluarganya. Dan seseorang yang mampu bertahan dalam segala tekanan dalam hidupnya ini disebut individu yang memiliki resilien (Setyowati, Hartati, \& Sawitri, 2010).

Optimis, keyakinan terhadap pemahaman kontrol diri akan lebih memiliki dukungan sosial, atau menjadi lebih efektif dalam pengerahan selama stress (Taylor, 2000). Optimis, pemahaman akan kontrol diri, dan self esteem berhubungan dengan usaha pemecahan masalah secara aktif (Taylor, 2000), yang memungkinkan individu untuk berhatihati atau mengimbangi peristiwa yang menekan sebelum seluruh implikasinya terasa.

Kemampuan itu untuk menanggulangi secara aktif dan proaktif dengan menghargai waktu dan kesempatan, akan meminimalkan pengaruh psikologis yang merugikan dari stress. Mood, depresi, perilaku yang sehat, dan hal lain yang secara potensial mendukung faktor psikososial, menjelaskan hubungan antara proses kognitif, pencarian makna, dan perkembangan kesulitan hidup. Banyak fakta yang menyebutkan bahwa kemampuan untuk mancari makna dalam peristiwa yang menekan atau traumatis, termasuk penederitaan akibat kesulitan ekonomi, biasanya memberikan penyesuaian psikologis (Taylor, 2000).

Banyak fakta mengindikasikan bahwa dampak positif dari peristiwa yang menekan atau kesulitan hidup adalah kemampuan seseorang dalam memaknai hidup, terlatih untuk memecahan masalah dengan lebih baik, meningkatkan kemampuan sosial, mampu menentukan skala prioritas dan menghargai hubungan sosial (Taylor, 2000). Dampak positif ini dapat terjadi jika respon individu terhadap kesulitan atau peristiwa yang menekan, tanpa keputusasaan, depresi, dan kehilangan tujuan atau makna.

Secara umum, pemahaman positif tentang diri, pemahaman akan kontrol diri, dan optimis melihat masa depan, merupakan sumber daya yang tidak hanya membantu seseorang menghadapi kesulitan dalam kehidupan sehari-hari, tetapi juga di asumsikan mampu mengatasi keadaan yang sangat menekan bahkan mengancam jiwa (Taylor, 2000). 
Pada kasus penderitaan akibat kemiskinan atau kesulitan ekonomi, sumberdaya tersebut adalah sebagai penyangga melawan kenyataan kesulitan memenuhi kebutuhan hidup, di mana individu menghadapi berbagai pengalaman tidak hanya dengan sumber psikologis yang berguna, tetapi juga dengan sumber resiliensi.

Resiliensi mempunyai pengertian sebagai suatu kemampuan untuk bangkit kembali (to bounce back) dari pengalaman emosi negatif dan kemampuan untuk beradaptasi secara fleksibel terhadap tuntutantuntutan yang terus berubah dari pengalamanpengalaman stress (Tugade \& Fredrickson, 2004). Seseorang yang memiliki kemampuan resiliensi memiliki penerimaan diri yang mendalam tentang diri sendiri maupun situasi personal secara positif dan mampu memaknai dengan baik peristiwa hidupnya.

Resiliensi ditandai dengan beberapa hal, yaitu: kemampuan seorang individu untuk bangkit kembali dari tekanan hidup, belajar dan mencari elemen positif dari lingkungannya untuk membantu kesuksesan proses beradaptasi dengan segala keadaan dan mengembangkan seluruh kemampuannya, walau berada dalam kondisi hidup tertekan, baik secara eksternal atau internal (Niaz, 2006).

Mackay dan Iwasaki menyatakan bahwa individu yang memiliki kemampuan resilien, sebagai berikut: (a) Mampu menentukan apa yang dikehendaki dan tidak terseret dalam lingkaran ketidakberdayaan; (b) Mampu meregulasi berbagai perasaan terutama perasaan negatif yang timbul akibat pengalaman traumatik; dan (c) Mempunyai pandangan atau kemampuan melihat masa depan dengan lebih baik (Yu \& Zhang, 2007).

Dari beberapa penjelasan tersebut dapat dikemukakan bahwa individu dengan resiliensi yang baik mampu menghadapi masalah dengan baik, mampu mengontrol diri, mampu mengelola stress dengan baik dengan mengubah cara berpikir ketika berhadapan dengan stres. Resiliensi memungkinkan individu untuk tetap fokus pada persoalan yang sesungguhnya, dan tidak menyimpang ke dalam perasaan dan pikiran yang negatif, sehingga individu bisa mengatasi resiko depresi dan banyak tantangan. Individu dengan resiliensi yang baik adalah individu yang optimis, yang percaya bahwa segala sesuatu dapat berubah menjadi lebih baik. Individu mempunyai harapan terhadap masa depan dan percaya bahwa individu dapat mengontrol arah kehidupannya. Optimis membuat fisik menjadi lebih sehat dan mengurangi kemungkinan menderita depresi. Resiliensi adalah kapasitas untuk merespon secara sehat dan produktif ketika berhadapan dengan kesengsaraan atau trauma, yang diperlukan untuk mengelola tekanan hidup sehari-hari (Reivich \& Shatté, 2002).

Dalam kenyataannya, tidak semua individu memiliki kemampuan resiliensi, tidak sedikit yang gagal untuk bertahan ditengah kesulitan dan tekanan hidup, terlebih lagi hidup di zaman teknologi globalisasi seperti sekarang ini di mana gaya hidup materialism, hedonism dan konsumerism sangat kuat. Kemiskinan atau kesulitan ekonomi dapat menjadi stressor tersendiri karena tidak dapat memenuhi segala tuntutan lingkungan. Semakin sedikitnya individu yang mampu menghadapi, bertahan dan bangkit dari penderitaan akibat kesulitan ekonomi terlebih sebagai mahasiswa di era yang serba materialism, mengangkat kasus resilien mahasiswa dalam konteks di atas menjadi signifikan. Untuk itu penelitian ini hendak menggali secara mendalam bagaimana resiliensi mahasiswa yang mengalami kemiskinan atau kesulitan ekonomi, sumber daya apa saja yang dimiliki dan faktor yang mempengaruhi kemampuan untuk resilien.

\section{Metode Penelitian}

Penelitian ini adalah deskriptif kualitatif dengan pendekataan studi kasus. Pendekatan ini digunakan dengan alasan adalah untuk mendapatkan pemahaman secara utuh dan terintegrasi tentang suatu fenomena yang terjadi pada individu tertentu. Terkait dengan fenomena yang ada, penelitian ini memiliki unit analisis yaitu resiliensi pada mahasiwa yang mengalami kesulitan ekonomi. Subjek penelitian ini adalah salah satu mahasiswa program studi Bimbingan Penyuluhan Islam Fakultas Dakwah dan Komunikasi Universitas Islam Negeri Raden Fatah Palembang, memiliki prestasi akademik, berasal dari keluarga miskin dan broken home. Ditambah dengan sumber data pendukung yaitu teman dekat dan keluarga. Teknik pengumpulan data menggunakan wawancara mendalam dan observasi partisipasi. Data kemudian dianalisa dengan teknik 
studi kasus yaitu, penjodohan pola, eksplanasi dan deret waktu.

\section{Hasil Penelitian dan Pembahasan}

\section{Hasil Penelitian}

Untuk mendapatkan gambaran mendalam tentang resiliensi subjek dan faktor yang mempengaruhinya, peneliti melakukan wawancara dan observasi partisipatif, di mana peneliti beraktivitas bersama subjek misalnya ketika subjek mengajar baik di bimbingan belajar maupun di rumah. Data hasil wawancara dan observasi kemudian dianalisa menggunakan teknik studi kasus yakni penjodohan pola, eksplanasi dan deret waktu.

Tiga tahap analisa tersebut mengasilkan gambaran resiliensi subjek dengan jelas. Berikut adalah tiga tahapan dimaksud:

a. Penjodohan Pola

1) Gambaran resiliensi mahasiswa yang mengalami kesulitan ekonomi

Resiliensi Prediksi Resiliensi Empiris

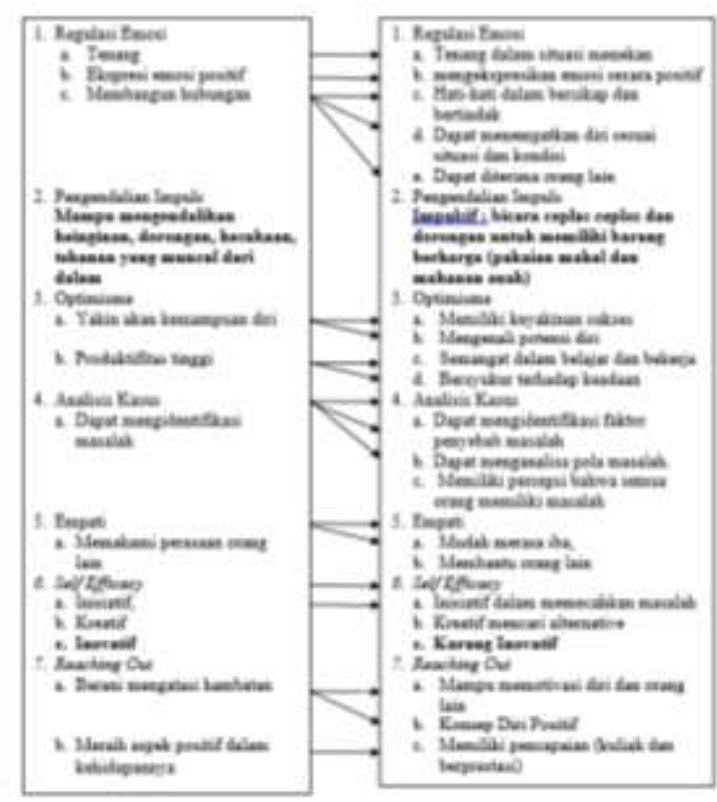

Gambar 1. Penjodohan Pola Resiliensi

Mahasiswa yang Mengalami Kesulitan

Ekonomi

Berdasarkan gambar di atas dapat dilihat dan disimpulkan bahwa subjek memiliki kemampuan resiliensi yang baik dalam menghadapi kesulitan ekonomi, meskipun ada beberapa aspek dari resiliensi yang rendah. Aspek yang di cetak tebal dan tidak ditandai dengan panah menandakan indikator rendah atau tidak dimiliki oleh subjek. Dari tujuh aspek resiliensi yang diungkap, enam di antaranya dimiliki dengan baik oleh subjek yaitu regulasi emosi, optimisme, analisis kasus, empati, self efficacy dan reaching out. Satu indikator dari self efficacy yakni inovatif tidak dimiliki oleh subjek.

2) Faktor yang mempengaruhi resiliensi mahasiswa dalam mengalami kesulitan ekonomi

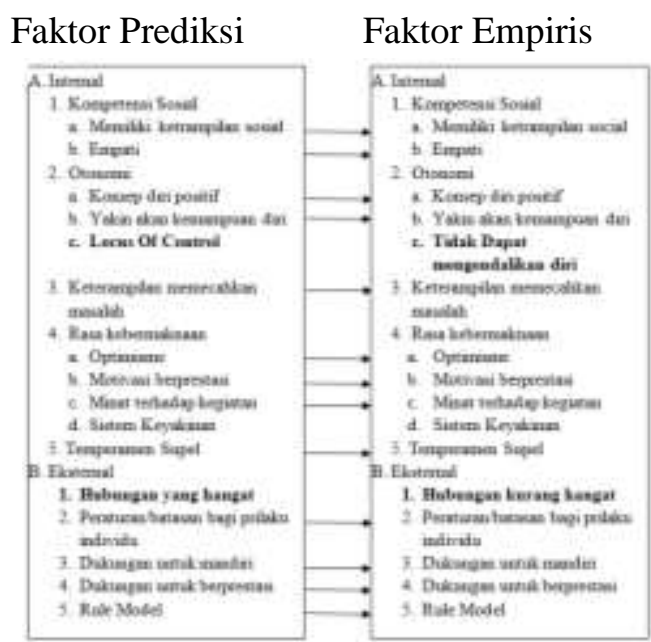

Gambar 2. Penjodohan Pola Faktor Yang Mempengaruhi Resiliensi

Kesimpulan yang dapat diambil dari perbandingan pola yang diprediksikan dengan pola yang berasal dari data empiris adalah bahwa sebagian besar faktor-faktor sebagai sumber resiliensi baik internal maupun eksternal dimiliki oleh subjek. Faktor yang berasal dari internal adalah keterampilan sosial, empati, konsep diri positif, yakin akan kemampuan diri, keterampilan memecahkan masalah, optimis, memiliki motivasi berprestasi, memiliki hobi, sistem keyakinan dan temperamen yang supel. Faktor resiliensi yang berasal dari eksternal adalah memiliki batasan perilaku, dukungan dari keluarga untuk mandiri, dukungan dari komunitas untuk berprestasi dan memiliki role model. Sementara itu locus of kontrol dan hubungan yang hangat tidak menjadi faktor yang mempengaruhi resiliensi subjek. 
b. Eksplanasi

1) Resiliensi mahasiswa yang mengalami kesulitan ekonomi

Berikut adalah gambaran aspek resiliensi yang nampak pada diri subjek penelitian, yang diperoleh dari hasil wawancara dan observasi.

Dalam aspek regulasi emosi, subjek menunjukkan ketenangan, kemampuan mengelola perasaannya dan mampu mengekspresikan emosi secara positif, subjek juga memiliki hubungan yang baik dan bisa diterima oleh orang lain khususnya temantemanya. Selain itu subjek juga memiliki kontrol diri yang baik dengan menunjukkan sikap kehati-hatian dalam bersikap dan bertindak. Subjek dapat menempatkan diri sesuai dengan keadaan dan dengan siapa subjek berinteraksi.

Dalam aspek pengendalian impuls. Subjek menunjukkan dorongan perilaku tertentu untuk mengekspresikan tekanan dan menahan keinginan yang belum tercapai. Impuls yang muncul adalah berbicara ceplas ceplos, ekspresi yang merendahkan orang lain. dan melakukan sesuatu yang bertentangan dengan keadaan. Misalnya, dorongan untuk memiliki barangbarang berharga, diantaranya pakaian yang mahal, makan yang enak. Dan dorongan itu sering subjek lakukan.

Selanjutnya gambaran resiliensi subjek dalam aspek optimisme adalah ditandai dengan semangat dalam menjalankan aktifitas baik dalam belajar maupun bekerja mencari uang untuk memenuhi kebutuhan hidupnya. Hariharinya disibukkan dengan berbagai aktifitas, bekerja dan belajar. Optimisme subjek juga ditandai dengan rasa syukur dengan keadaan walaupun dengan segala keterbatasan yang ada. Syukur itu muncul dari interaksinya dengan masyarakat sekitar tempat kontrakan subjek yang banyak mengalami kesulitan hidup. Subjek juga sering menyaksikan tayangan ditelevisi yang mengisahkan kehidupan orangorang yang kurang beruntung. Hal ini memberikan kelegaan bagi subjek karena ternyata masih banyak orang lain yang lebih susah dibanding dirinya. Dalam hal harapan sebagai indikator optimisme, subjek memiliki harapan yang sangat kuat bahwa kehidupannya pasti akan berubah. Subjek banyak terinpirasi dari kisah-kisah yang ia saksikan di televisi maupun yang ia baca. Kisah-kisah tersebut mengubah persepsinya tentang kesuksesan, bahwa keberhasilan itu dimulai dengan penderitaan, sehingga penderitaannya yang ia alami menjadi titik balik yang melahirkan harapan.

Aspek selanjutnya yang mengindikasikan resiliensi pada diri subjek adalah kemampuannya menganalisa masalah, yang ditandai kengan tiga cara berpikir eksplanatori. Cara berpikir pertama (saya-bukan saya), secara personal subjek beranggapan bahwa kesulitan hidup keluarganya, terutama masalah ekonomi dikarenakan ayahnya yang tidak bertanggungjawab, menelantarkan subjek, ibu dan saudara-saudaranya. Subjek bahkan sering merasa kesal dengan ulah ayahnya. Dalam tipe berpikir kedua yakni dimensi permanen (selalutidak selalu), subjek meyakini bahwa penderitaan tidak akan selamanya, kegagalan, kesulitan pasti akan berakhir. Cara berpikir ketiga dalam menganalisa masalah adalah pervasive (semua-tidak semua). Dalam hal ini subjek menganggap bahaya semua orang memiliki masalahnya sendiri-sendiri. Semua orang pasti punya masalah. Hanya saja masalahnya berbeda-beda. Sehingga subjek merasa bisa menghadapi kesulitan hidupnya karena tidak hanya dia yang mengalaminya.

Kemampuan resilien pada subjek juga dapat terlihat pada aspek empati yang ditandai dengan kepedulian pada sesama dan sikap sosial yang tinggi. Dalam hal ini subjek memiliki kepedulian pada sesama dengan ditandai mudahnya merasa iba pada orang lan yang kesusahan dan merasa jengkel pada orang yang tidak memiliki perasaan yakni yang memperlakukan orang lan tidak semestinya. Indikator sikap sosial yang tinggi di tunjukkan dengan tindakannya membantu orang lain dengan cara menyisihkan uang dari hasil kerjanya untuk diberikan pada orang yang kurang beruntung. Selain itu subjek juga menunjukkan kepeduliannya tidak hanya dalam bentuk materi tetapi dalam bentuk lain seperti 
memberikan bimbingan belajar bagi anak-anak yang orang tuanya kurang mampu.

Aspek lain dari resiliensi adalah selfefficacy, yakni kemampuannya memecahkan masalah atau menghadapi kesulitan. Aspek ini ditandai dengan inisiatif dalam menyelesaikan masalah, kreatif, inovatif dan bertanggung jawab. Semua indikator self-efficacy tersebut dimiliki oleh subjek kecuali indikator inovatif. Dalam upayanya memenuhi kebutuhan seharihari dan biawa kuliah, subjek sudah pernah mengalami pekerjaan dalam berbagai macam mulai dari pejual es keliling, pembantu rumah tangga, penjual gorengan, pencuci piring dirumah makan/kantin, karyawan di took ATK, mengajar di sekolah diniyah Muhammadiyah, les privat mengaji, subjek juga mencoba bisnis online, yakni memasarkan salah satu produk kosmetik.

Aspek terakhir dari resiliensi adalah kemampuan untuk bangkit dari penderitaan (reaching out) yang ditandai dengan kemampuannya memotivasi diri dan orang lain, tidak mudah menyerah, memiliki potensi dan modal sukses, memiliki pencapaian dan kesuksesan. Subjek dengan penuh percaya diri sering memberi motivasi kepada temantemannya yang sedang mengalami masalah. Subjek juga sering menasehati anak-anak didiknya di sekolah ataupun anak-anak yang les. Subjek memiliki mental juang yang tinggi, mental juang ini diperoleh subjek dari pengalaman hidupnya sejak kecil yang harus bekerja sendiri untuk mendapatkan apa saja yang ia inginkan. Termasuk keinginan yang bersifat primer misalnya pakaian. Selain itu subjek terlihat sangat percaya diri, dia menilai dirinya positif sehingga penampilannya meyakinkan. Subjek juga mampu mengenali potensi yang dimiliki, subjek mengaku bahwa ia dapat berkomunikasi dengan lancar, dapat menyampaikan gagasan dengan baik, memiliki sence of humor (rasa humor), lancar dan fasih membaca Al-Qur'an.

Kemampuan untuk bangkit juga ditandai dengan pencapaian-pencapaian terhadap apa yang ia inginkan. Pencapaian yang terpenting adalah keinginannya untuk kuliah telah diperoeh. Subjek sekarang adalah mahasiswa semester 8 program studi Bimbingan Penyuluhan Islam Fakultas Dakwah dan Komunikasi UIN Raden Fatah Palembang yang sedang menyelesaikan tugas akhir. Keinginan lain yang telah dicapai adalah subjek dapat membel sepeda sendiri, membeli pakaian yang bagus dan kebutuhan lainnya.

Sukses dalam kuliah sebagai indikator kemampuan untuk bangkit juga ditunjukkan oleh subjek dengan prestasi akademik yang tinggi. Rata-rata IPK Tia semester di atas 3,5. Selain itu subjek dapat menyelesaikan semua tugas perkuliahannya dengan baik sesuai dengan waktu yang ditentukan.

2) Faktor yang mempengaruhi resiliensi mahasiswa yang mengalami kesulitan ekonomi

Secara internal, banyak faktor yang dimiliki oleh subjek sehingga subjek mampu menghadapi segala kesulitan hidupnya dan mampu menyelesaikannya. Faktor internal yang dimaksud adalah faktor yang berasal dari dalam diri subjek. yaitu kompetensi sosial di mana subjek memiliki keterampilan sosial dalam bentuk keterampilan berkomunikasi dan berinteraksi. Subjek mampu bergaul dengan baik dan diterima oleh orang lain. selain itu subjek juga memiliki sikap empati yang baik. Sikap empati ini ditandai dengan mudahnya merasa iba melihat orang lain yang kesusahan, menyisihkan sebagian uangnya secara rutin untuk diberian pada orang yang membutuhkan dan membatu anak-anak dari keluarga yang tidak mampu dengan memberikan bimbingan belajar.

Berdasarkan perbandingan antara pola prediksi dengan pola yang berasal dari data empiris di atas, dapat terlihat bahwa hanya beberapa saja faktor yang tidak dimiliki oleh subjek, yaitu aspek otonomi yang berasal dari faktor internal berupa faktor pengendalian oleh individu dan aspek hubungan yang hangat dengan orang lain yang berasal dari faktor eksternal.

Tidak dimilikinya faktor pengendalian oleh individu yang dimaksud adalah subjek menganggap bahwa semua adalah diluar 
kemampuannya untuk mengendalikan. Dengan kata lain semua yangterjadi adalah takdir. Keyakinan seperti ini tidak mendukung bagi terbentuknya resiliensi pada seseorang. Sebaliknya, resiliensi akan dipengaruhi oleh keyakinan bahwa semua kesulitan dan hambatan yang menimpanya masih dalam batas seseorang untuk mengendalikannya.

Faktor lain yang tidak dimiliki oleh subjek adalah hubungan yang hangat terutama dari orang-orang terdekatnya. Kehangatan emosional tidak subjek dapatkan baik dari ibunya maupun saudara-saudaranya. Keseharian ibunya sangat sibuk karena harus banting tulang bekerja mencari nafkah, tidak ada waktu bagi ibunya untuk bercengkrama dengan anak-anaknya. Begitupun dengan saudara-saudaranya, karena sejak SMP, subjek tidak dirumah, subjek sekolah dipondok pesantren yang jauh dari tempat tinggalnya. Demikian juga saudara-saudaranya, sudah memiliki keluarga masing-masing dan tidak tinggal serumah lagi dengan subjek. Saudara subjek rata-rata menikah di usia muda.

c. Deret Waktu

Fakta-fakta dan peristiwa yang dialami oleh subjek terkait dengan aspek-aspek resiliensi dan indikator dari masing-masing aspeknya termasuk faktor yang mempengaruhinya dianalisa menurut urutan terjadinya peristiwa, perilaku, pengalaman dan lain-lain. Dengan tujuan dapat menggambarkan dengan jelas fakta, kejadian atau prilaku dari sisi kedalamannya, rentangnya, interaksi dengan hal lainnya.

Tabel 1. Deret Waktu Resiliensi dan

Faktornya

\begin{tabular}{|c|c|c|c|c|c|c|}
\hline \multirow[b]{2}{*}{ No } & \multirow[b]{2}{*}{ Keterangan } & \multicolumn{5}{|c|}{ Tahun } \\
\hline & & $\begin{array}{l}1996- \\
2002\end{array}$ & $\begin{array}{l}2002- \\
2008\end{array}$ & $\begin{array}{l}2008- \\
2011\end{array}$ & $\begin{array}{r}2011- \\
1014\end{array}$ & $\begin{array}{c}\text { 2014- } \\
\text { Sekar } \\
\text { ang }\end{array}$ \\
\hline \multirow[t]{11}{*}{1.} & Gambaran resiliensi & & & & & \\
\hline & a. Ketenangan & & & & & \\
\hline & $\begin{array}{ll}\text { b. } & \begin{array}{l}\text { Ekspresi emosi } \\
\text { positif }\end{array}\end{array}$ & & & & & \\
\hline & $\begin{array}{ll}\text { c. Hubungan dengan } \\
\text { orang lain }\end{array}$ & & & & & \\
\hline & d. Bersikap hati-hati & & & & & \\
\hline & e. Tidak Impulsive & & & & & \\
\hline & f. $\quad$ Semangat & & & & & \\
\hline & $\begin{array}{ll}\text { g. } & \begin{array}{l}\text { Mensyukuri } \\
\text { keadaan }\end{array}\end{array}$ & & & & & \\
\hline & h. Memiliki harapan & & & & & \\
\hline & i. $\quad$ Mudah merasa iba & & & & & \\
\hline & $\begin{array}{ll}\text { j. } & \text { Peduli sesama } \\
\end{array}$ & & & & & \\
\hline
\end{tabular}

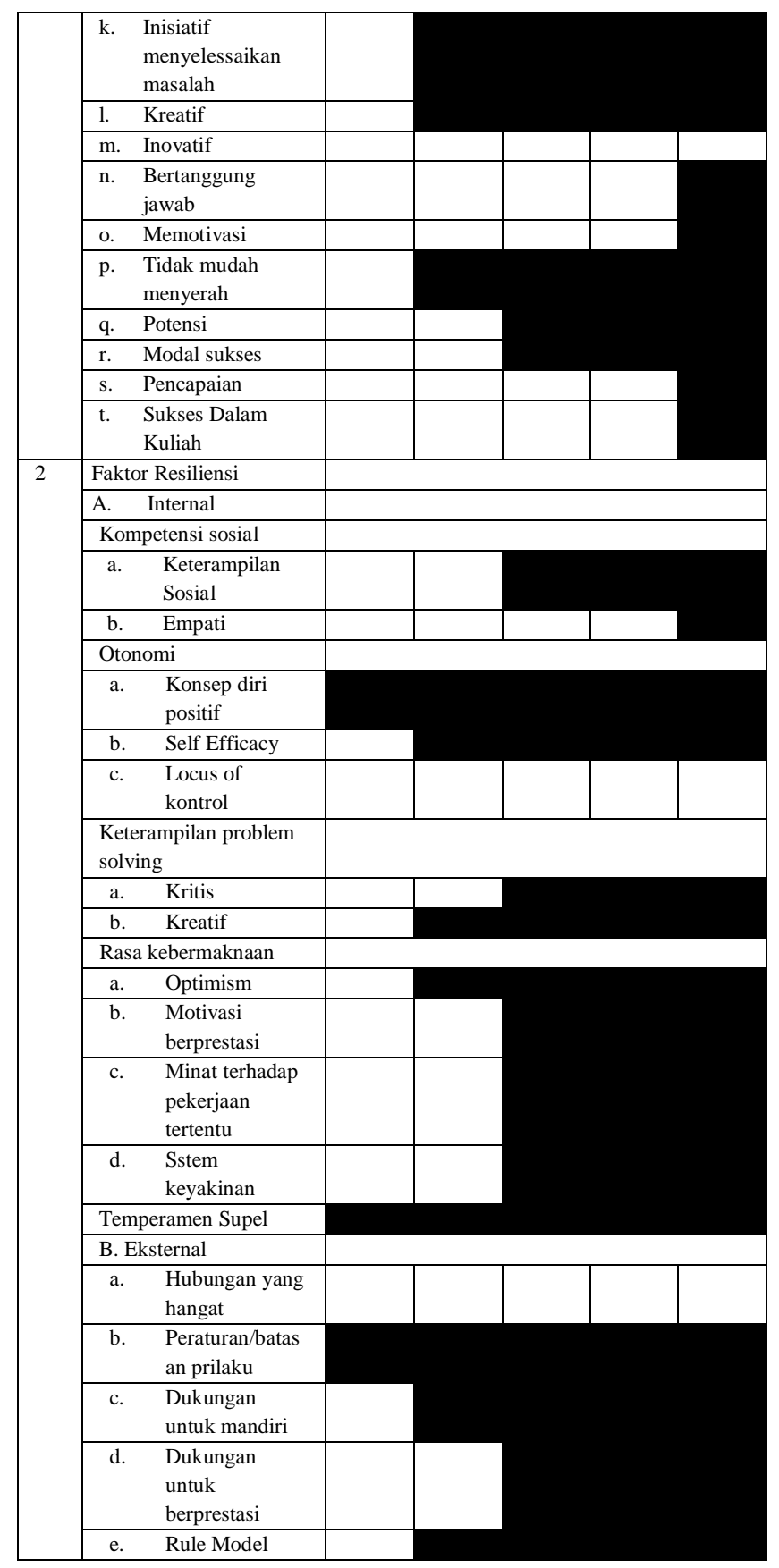

Keterangan :

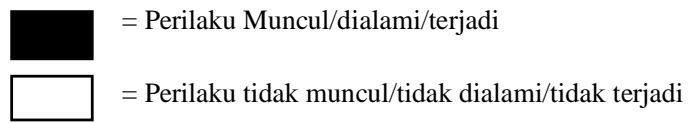

\section{Pembahasan}

Berdasarkan hasil analisis, maka ditemukan subjek memiliki resiliensi dalam menghadapi kemiskinan atau kesulitan ekonomi yang dialaminya. Hal ini dapat dilihat misalnya dari aspek regulasi emosi. Subjek menunjukkan sikap tenang. Subjek memiliki cara tersendiri untuk menghadapi orangorang/teman-temannya, rasa malu, rasa capek dan lain-lain. Sikap tenang yang subjek miliki membuat 
subjek dapat melakukan banyak hal, misalnya melakukan kegiatan-kegiatan yang dapat mengalihkan perasaannya. Reivich \& Shatte (2002) juga menjelaskan bahwa sikap tenang yang dimiliki oleh individu akan memudahkan seseorang mengendalikan emosinya. Ketenangan juga dapat menjaga tetap fokus walaupun dalam keadaan banyak gangguan. Dengan sendirinya dapat mengurangi stress yang mungkin terjadi

Ketika mengalami kekecewaan, kelelahan, atau tekanan yang lain, subjek meluapkan emosinya dengan melakukan hal-hal yang membuat dirinya senang dan melupakan perasaan negatifnya, misalnya jalan-jalan, makan-makan, atau belanja barang. Apa yang dilakukannya hanya untuk mengekpresikan tekanan yang ia rasakan. Menurut Miranti (2012), individu yang memiliki kemampuan meregulasi emosi pada seseorang dapat dilihat dari kemampuannya mengendalikan diri ketika merasa kesal, mampu mengatasi rasa sedih, cemas, dan marah, sehingga mempercepat dalam pemecahan suatu masalah.

Indikator regulasi emosi lainnya yang dimiliki oleh subjek adalah hati-hati dalam bersikap dan bertindak, mampu menempatkan diri sesuai dengan keadaan sehingga subjek mudah diterima oleh orang lain. Hal ini menunjukkan bahwa subjek mampu membangun hubungan baik dengan orang lain. Kemampuan mengembangkan hubungan yang jujur, saling mendukung dan berkualitas merupakan indikasi seseorang memiliki resiliensi (Wolin \& Wolin, 1999). Greef (2005) menjelaskan bahwa mengekspresikan perasaan secara tepat merupakan bagian dari resiliensi, bahkan Greef menegaskan bahwa seseorang yang mampu mengekspresikan emosi baik yang positif maupun negatif merupakan hal yang sehat karena tidak semua emosi yang dirasakan harus dikendalikan.

Dalam hal pengendalian impuls, ketika subjek tidak dapat mencapai cita-citanya/keinginannya, misalnya berfoto keluarga terutama dengan ayahnya, membeli printer untuk menyelesaikan tugas akhirnya, membeli motor, karena selama ini ke mana-mana naik sepeda. Tetapi keinginan yang belum tersampaikan tersebut tidak membuat subjek merasa tertekan. Hal ini menandakan bahwa subjek mampu menahan keinginannya. Kemampuan individu untuk mengendalikan keinginan, dorongan, kesukaan, serta tekanan yang muncul dari dalam diri, menurut Reivich \& Shatte (2002) adalah ciri dari pengendalian impuls.

Namun, subjek menunjukkan beberapa prilaku impulsif. Subjek suka berbicara ceplas ceplos, berekspresi seolah meremehkan orang lain. Selain itu sikap impulsif subjek ditunjukkan dengan tidak mampu menahan diri untuk membeli barang terutama pakaian, alat kosmetik dan makanan enak. Jika subjek memiliki uang, maka yang pertama ia beli adalah barang-barang tersebut, baru yang lainnya.

Aspek lain dalam resiliensi adalah optimism, yaitu kemampuan melihat masa depan cemerlang (Reivich \& Shatté, 2002). Subjek memiliki semangat dalam menjalani kehidupannya saat ini dan menerima semua keadaan yang diberikan oleh Tuhan untuknya. Menurut subjek, kesulitan hidup, kemiskinan yang dialami sejak kecil merupakan penyebab dirinya memiliki ketangguhan dan memilki keberanian untuk mengambil resiko, kekuatan jiwa ini adalah modal bagi subjek untuk bertahan dan bangkit mengubah keadaan. Subjek memandang sebuah hambatan, kesulitan dan penderitaan yang dialami dengan makna positif. Subjek sangat yakin bahwa kehidupannya akan berubah, dapat meraih kesuksesan karena subjek merasa memiliki kemampuan untuk meraih citacitanya.

Peterson dan Chang mengungkapkan bahwa optimisme sangat terkait dengan karakteristik yang diinginkan oleh individu, kebahagiaan, ketekunan, prestasi dan kesehatan. Individu yang optimis percaya bahwa situasi yang sulit suatu saat akan berubah menjadi situasi yang lebih baik (Siebert, 2005).

Aspek selanjutnya yang menunjukkan sikap mental resilien adalah kemampuan menganalisa masalah, terutama faktor penyebanya. Seligman (Reivich \& Shatté, 2002) mengidentifikasikan tiga gaya berpikir explanatory yang erat kaitannya dengan kemampuan causal analysis. Cara berpikir pertama (saya-bukan saya), secara personal subjek beranggapan bahwa kesulitan hidup keluarganya, terutama masalah ekonomi dikarenakan ayahnya yang tidak bertanggungjawab, menelantarkan subjek, ibu dan saudara-saudaranya. Subjek bahkan sering merasa kesal dengan ulah ayahnya. Dalam tipe 
berpikir kedua yakni dimensi permanen (selalu-tidak selalu), subjek meyakini bahwa penderitaan tidak akan selamanya, kegagalan, kesulitan pasti akan berakhir. Cara berpikir ketiga dalam menganalisa masalah adalah pervasive (semua-tidak semua). Dalam hal ini subjek menganggap bahaya semua orang memiliki masalahnya sendiri-sendiri. Semua orang pasti punya masalah. Hanya saja masalahnya berbeda-beda. Sehingga subjek merasa bisa menghadapi kesulitan hidupnya karena tidak hanya dia yang mengalaminya. Dan tidak selamanya manusia itu kehidupannya akan menderita. Hidup ibarat roda yang terus berputar. Subjek yakin bahwa suatu saat roda kehidupannya akan berputar kearah kesuksesan.

Kemampuan resilien pada subjek juga dapat terlihat pada aspek empati yang ditandai dengan kepedulian pada sesama dan sikap sosial yang tinggi. Dalam hal ini subjek memiliki kepeduian pada sesama dengan ditandai mudahnya merasa iba pada orang lan yang kesusahan dan merasa jengkel pada orang yang tidak memiliki perasaan yakni yang memperlakukan orang lan tidak semestinya. Indikator sikap sosial yang tinggi di tunjukkan dengan tindakannya membantu orang lain dengan cara menyisihkan uang dari hasil kerjanya untuk diberikan pada orang yang kurang beruntung. Selain itu subjek juga menunjukkan kepeduliannya tidak hanya dalam bentuk materi tetapi dalam bentuk lain seperti memberikan bimbingan belajar bagi anakanak yang orangtuanya kurang mampu. Perasaan yang sensitif dan ringan tangan membantu kesusahan orang lain adalah indikator empati sebagaimana dikemukakan oleh Reivich \& Shatte (2002) bahwa empati adalah kemampuan untuk merasakan perasaan orang lain, simpatik, dan mencoba menyelesaikan masalah.

Aspek resiliensi lainnya adalah Self-efficacy. Self-efficacy yang tinggi akan sangat mudah dalam menghadapi tantangan. Individu tersebut tidak merasa ragu karena memiliki kepercayaan yang penuh dengan kemampuan dirinya (Bandura, 1994). Subjek memiliki indikasi memiliki self efficacy yang baik. Hal ini ditandai dengan inisiatif menyelesaikan masalahnya sendiri dengan melakukan dan usaha tanpa mengenal lelah dengan mencoba berbagai pekerjaan yang dapat menghasilkan uang. Mulai dari berjualan, bekerja sebagai buruh, sampai pekerjaan yang membutuhkan keahlian misalnya mengajar. Selain inisiatif, subjek juga kreatif mencari alternatif pekerjaan mulai dari buruh kasar sampai pekerjaan yang memerlukan keahlian. Dikatakan oleh Wolin \& Wolin (1999) bahwa seorang individu yang resilien mampu secara kreatif menggunakan apa yang tersedia untuk pemecahan masalah dalam situasi sumber daya yang terbatas. Selain itu, bentuk-bentuk kreativitas juga terlihat dalam minat, kegemaran, kegiatan kreatif dari imajinatif.

Aspek terakhir yang dimiliki subjek adalah kemampuan untuk mewujudkan impiannya untuk kuliah dan meraih prestasi akademik dalam kuliahnya. Kemampuan individu untuk meraih halhal positif dalam kondisi sangat menekan di seebut reaching out atau pencapaian. Sebagaimana dikemukakan oleh Reivich \& Shatte (2002) bahwa reaching out merupakan kemampuan individu keluar dan meraih aspek positif dari kehidupan setelah musibah yang menimpa. Subjek bahkan mampu memotivasi orang lain untuk bersungguh-sunggu dalam belajar, tidak menyia-nyiakan kesempatan dan kemudahan dalam hidup. Subjek memotivasi agar tidak selalu berpangku tangan dan menghabiskan waktu dengan hal-hal yang tidak berguna.

Mengapa subjek memiliki sikap mental yang resilien dalam menghadapi kemiskinan? berdasarkan hasil analisis studi kasus terutama hasil analisis deret waktu dapat terlihat bahwa secara internal subjek memiliki kepercayaan diri yang tinggi karena konsep diri yang positif, dan sejak kecil pula subjek memiliki kepribadian riang dan supel, mudah bergaul. Hal-hal tersebut adalah modal internal yang mempengaruhi resiliensi subjek.

Secara eksternal, subjek dari kecil dididik oleh ibunya dengan aturan dan norma-norma agama sehingga memiliki batasan dalam bertindak dan perilakunya terarah. Faktor lainnya yang mempengaruhi kesuksessan subjek menjadi mahasiswa berprestasi ditengah kemiskinan adalah faktor keluarga, yaitu ibunya yang sejak subjek kecil banting tulang menghidupi ketujuh anaknya. Subjek merasa kasihan pada ibunya sehingga bertekad untu dapat mengubah keadaan dengan melanjutkan pendidikan setinggi mungkin dengan harapan mendapatkan penghidupan yang layak. Menurut Everall (2006), keterikatan para anggota keluarga amat berpengaruh dalam pemberian dukungan 
terhadap anggota keluarga yang mengalami kesulitan untuk dapat bertahan dan memperbaiki kehidupan bersama. Untuk mencapai resiliensi dibutuhkan individu yang signifikan untuk membantu pencapaiannya, salah satunya adalah keluarga. Individu tidak akan mampu mencapai resiliensi seorang diri (Nasiton, 2011). Individu yang significan bagi subjek adalah ibunya, dialah yang selalui memotivasi subjek untuk mandiri. Namun dalam hal kedekatan secara emosional dengan ibunya sebenarnya tidak dirasakan oleh subjek, karena ibunya sibuk bekerja berjualan, jarang beriteraksi dengan subjek. Selain itu sejak SMP subjek sudah sekolah dipodok pesantren. Ada sosok lain yang berpengaruh dalam kehidupannya tapi bukan keluarga, yaitu kepala sekolah ketika Sekolah Dasar. Subjek merasa memilki ayah karena kepala sekolah tersebut memperlakukan subjek seperti anaknya. Kepala sekolah ini juga menjadi role model bagi subjek dalam belajar dan bekerja.

\section{Kesimpulan}

Hasil penelitian menunjukkan bahwa mahasiswa memiliki resiliensi dalam menghadapi kesulitan ekonomi yang ditandai dengan kemampuan dalam regulasi emosi, self efficacy yakni memiliki inisiatif, mampu menyelesaikan masalah, kreatif dan bertanggung jawab. Subjek juga memiliki sikap optimisme, mampu berpikir dan menganalisa masalah, memiliki motivasi berprestasi, mampu mengenali potensi diri, memiliki modal kesuksean dan telah memiliki pencapaian dal hidupnya yang salah satunya adalah prestasi akademik. Faktor yang mempengaruhi resiliensi mahasiswa yang mengalami kesulitan ekonomi adalah faktor internal berupa, keterampilan sosial, empati, konsep diri positif, self-efficacy dan self esteem, memiliki rasa kebermaknaan yakni optimis, motivasi, minat, sistem keyakinan dan karakter yang humoris. Sedangkan faktor eksternal dipengaruhi oleh dukungan keluarga dan teman, norma keluarga dan rule model

\section{Daftar Pustaka}

Buck, R., \& Deutsch, J. (2014). Effects of poverty on education. Journal of Human Sciences, 11(2), 1139-1148.

Crosnoe, R., Mistry, R. S., \& Elder Jr, G. H. (2002).
Economic disadvantage, family dynamics, and adolescent enrollment in higher education. Journal of marriage and family, 64(3), 690702.

Everall, R. D., Altrows, K. J., \& Paulson, B. L. (2006). Creating a future: A study of resilience in suicidal female adolescents. Journal of Counseling \& Development, 84(4), 461-470.

Greef, A. (2005). Resilience: Personal Skills for Effective Learning. UK: Crown House Publishing Ltd.

Juby, C., \& Rycraft, J. R. (2004). Family preservation strategies for families in poverty. Families in Society, 85(4), 581-587.

Karini, P. (2018). Pengaruh Tingkat Kemiskinan Terhadap Angka Partisipasi Sekolah Usia 1618 Tahun di Provinsi Kepulauan Bangka Belitung. AL-ISHLAH: Jurnal Pendidikan, 10(1), 103-115.

McLoyd, V. C. (1990). The impact of economic hardship on Black families and children: Psychological distress, parenting, and socioemotional development. Child development, 61(2), 311-346.

Milioni, M., Alessandri, G., Eisenberg, N., Castellani, V., Zuffianò, A., Vecchione, M., \& Caprara, G. V. (2015). Reciprocal relations between emotional self-efficacy beliefs and ego-resiliency across time. Journal of personality, 83(5), 552-563.

Nasiton, S. (2011). Resiliensi Daya Pegas Menghadapi Trauma Kehidupan. Medan: USU Press.

Niaz, U. (2006). Role of faith and resilience in recovery from psychotrauma. Pakistan journal of medical sciences, 22(2), 204.

Orthner, D. K., Jones-Sanpei, H., \& Williamson, S. (2004). The resilience and strengths of lowincome families. Family relations, 53(2), 159167.

Rasyid, M., \& Suminar, D. R. (2012). Hubungan antara peer attachment dengan regulasi emosi remaja yang menjadi siswa di boarding school SMA Negeri 10 Samarinda. Jurnal psikologi pendidikan dan perkembangan, 1(3), 1-7.

Reivich, K., \& Shatté, A. (2002). The resilience faktor: 7 essential skills for overcoming life's inevitable obstacles. Broadway books. 
Setyowati, A., Hartati, S., \& Sawitri, D. R. (2010).

Hubungan Antara Kecerdasan Emosional

Dengan Resiliensi Pada Siswa Penghuni

Rumah Damai. Jurnal Psikologi, 7(1), 67-77.

Tugade, M. M., \& Fredrickson, B. L. (2004).

Resilient individuals use positive emotions to bounce back from negative emotional experiences. Journal of personality and sosial psychology, 86(2), 320. 
